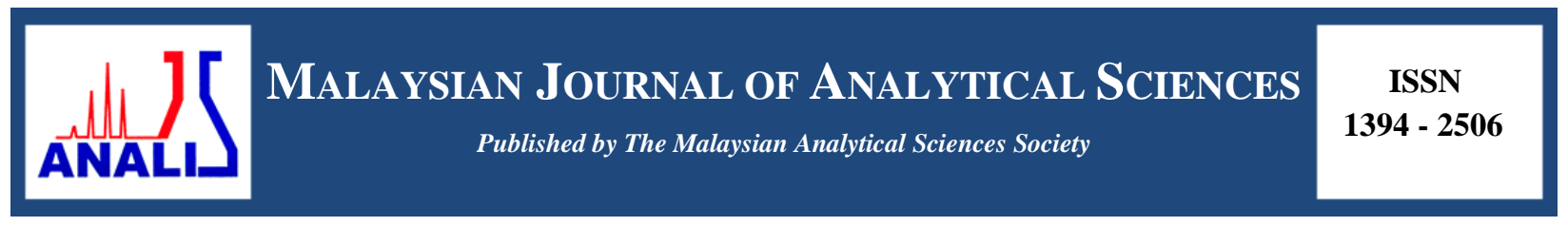

\title{
CHEMICAL CHANGES OF SHORT-BODIED MACKEREL (Rastrelliger brachysoma) MUSCLE AT CHILLED AND FROZEN STORAGE
}

\author{
(Perubahan Kimia ke atas Tisu Otot Ikan Kembung Bertubuh Pendek (Rastrelliger brachysoma) \\ Pada Penyimpanan Suhu Dingin dan Sejuk Beku) \\ Emilia Azrina Mohd Bakri, Norizzah Abd Rashid*, Cheow Chong Seng, Anida Yusoff, Fazilah Fazilin Juhari \\ Department of Food Technology, \\ Faculty of Applied Sciences, \\ Universiti Teknologi MARA, 40450 Shah Alam, Selangor, Malaysia
}

*Corresponding author: norizzah850@salam.uitm.edu.my

Received: 24 February 2015; Accepted: 27 October 2015

\begin{abstract}
This study was carried out to evaluate the chemical changes in short-bodied mackerel during chilled $\left(4{ }^{\circ} \mathrm{C}\right)$ and frozen $\left(-18{ }^{\circ} \mathrm{C}\right)$ storage for 18 days. The chemical changes were monitored at three days interval using Peroxide Value (PV), Thiobarbituric Acid (TBA), Total Volatile Base Nitrogen (TVBN) and Trimethylamine (TMA) tests. The PV of both chilled and frozen mackerel significantly increased $(\mathrm{p}<0.05)$ with storage time and the rate was significantly higher in chilled than frozen mackerel. Based on the results, the chilled and frozen mackerel started to become rancid at day 15 and day 18, respectively. Similar trend was observed for TBA value, where the malonaldehyde content significantly increased $(\mathrm{p}<0.05)$ for both chilled and frozen mackerel with storage time, and the rate of increase was higher in chilled than frozen mackerel. The TVBN and TMA of chilled mackerel increased significantly during storage time, but the values declined in frozen mackerel which might be due to inhibitory effects of freezing on the bacterial activities and hence avoid accumulation of TMA. Based on the chemical analyses, chilled mackerel spoiled rapidly compared to frozen mackerel.
\end{abstract}

Keywords: short-bodied mackerel, thiobarbituric acid, peroxide value, total volatile base nitrogen, trimethylamine

\begin{abstract}
Abstrak
Kajian ini telah dijalankan untuk menilai perubahan kimia dalam tisu otot ikan kembung bertubuh pendek semasa penyimpanan pada suhu dingin $\left(4{ }^{\circ} \mathrm{C}\right)$ dan suhu sejuk beku $\left(-18{ }^{\circ} \mathrm{C}\right)$ selama 18 hari. Perubahan kimia telah dipantau selang tiga hari menggunakan ujian Nilai Peroksida (PV), Asid Tiobarbiturik (TBA), Jumlah Bes Nitrogen Meruap (TVBN) dan Trimetilamina (TMA). Nilai Peroksida ikan kembung pada kedua-dua suhu dingin dan sejuk beku meningkat dengan ketara (p < 0.05) semasa penyimpanan dan kadar peningkatan PV lebih ketara bagi ikan kembung yang disimpan pada suhu dingin berbanding suhu sejuk beku. Berdasarkan keputusan yang diperolehi, ikan kembung pada suhu dingin dan sejuk beku masing - masing menjadi tengik pada hari ke 15 dan ke 18 penyimpanan. Pola yang sama diperolehi bagi nilai TBA, di mana kandungan malonaldehid meningkat dengan ketara $(\mathrm{p}<0.05)$ bagi kedua-dua ikan kembung pada suhu dingin dan suhu sejuk beku semasa penyimpanan, dan kadar kenaikan malonaldehid adalah lebih tinggi terhadap ikan kembung pada suhu dingin. Nilai TVBN dan TMA ikan kembung pada suhu dingin meningkat dengan ketara semasa penyimpanan. Walau bagaimanapun kedua-dua nilai ini menurun bagi ikan kembung sejuk beku disebabkan kesan perencatan sejuk beku terhadap aktiviti bakteria dan seterusnya mengelakkan pengumpulan TMA. Berdasarkan analisis kimia ini, ikan kembung dingin rosak lebih cepat berbanding dengan ikan kembung sejuk beku.
\end{abstract}

Kata kunci: Ikan kembung bertubuh pendek, asid tiobarbiturik, nilai peroksida, jumlah bes nitrogen meruap, trimetilamina 


\section{Introduction}

Fish is one of the most highly perishable food products [1] due to high concentrations of free amino acids and volatile bases [2]. In addition, fish is highly susceptible to oxidative rancidity due to large amount of phospholipids containing polyunsaturated fatty acids. Sallam [3] reported that there is a complex process of deterioration occurs in fish which are physical, chemical and microbiological reactions degrading the quality of fish thereby may cause approval or rejection after prolonged storage.

Oxidative rancidity is an autoxidation or hydrolysis process of fats into short-chain aldehydes and ketones and is responsible for rancid flavor and odour. When this process occurs in food, it may result in food rejection even though the food had been held under chilled or frozen storage. Nowadays, Total Volatile Base Nitrogen (TVBN) and Trimethylamine (TMA) are widely used to determine the quality of fish and are very good indicators to measure the trimethylamine, dimethylamine, ammonia and other basic nitrogenous compounds which were produced by spoilage bacteria, autolytic enzyme at frozen temperature, deamination of amino-acids and nucleotide catabolites that are associated with fish spoilage.

Monitoring fish quality is important in many food industries to produce high quality product when fish was used as one of the ingredients. Hence, the objective of this study was to evaluate the chemical changes in muscle tissue of short-bodied mackerel based on PV, TBA, TVBN and TMA tests during 18 days of storage at chilled $\left(4{ }^{\circ} \mathrm{C}\right)$ and frozen $\left(-18{ }^{\circ} \mathrm{C}\right)$ temperature.

\section{Sample preparation}

\section{Materials and Methods}

Short-bodied mackerel (Rastrelliger brachysoma) with average size of 15 to $20 \mathrm{~cm}$ and weight of 50 to $100 \mathrm{~g}$ were bought fresh from wet market, Kuala Pilah, Negeri Sembilan, Malaysia. The fish were placed in boxes with ice and immediately delivered to the laboratory. Short-bodied mackerel were eviscerated and cleaned before packed in the plastic containers. Then, samples were stored at chilled $\left(4^{\circ} \mathrm{C}\right)$ and frozen $\left(-18{ }^{\circ} \mathrm{C}\right)$ temperature for 18 days and were analysed for PV, TBA, TVBN and TMA every 3 days.

\section{Chemical analyses}

All the chemicals used were of analytical grade and were obtained from CHEMOLAB Supplies, Seri Kembangan, Selangor, Malaysia.

\section{Peroxide value (PV) test}

Peroxide value of short-bodied mackerel was determined according to method described by AOAC [4] and oil was extracted based on method proposed by Razak et al [5]. The results were determined in terms of miliequivalent of peroxides per $\mathrm{kg}$ of fish.

\section{Thiobarbituric acid (TBA) test}

The TBA was measured according to the method of Tokur et al [6]. Ten gram of fish was mixed with $100 \mathrm{~mL}$ of 0.2 $\mathrm{M}$ hydrochloric acid and homogenised prior to distillation (Behr Labor-Technik GmbH, Germany). Approximately within 5 minutes, $50 \mathrm{~mL}$ of distillate was collected. An amount $5 \mathrm{~mL}$ of distillate was pipetted into test tube and 5 $\mathrm{mL}$ of TBA reagent was added. The sample was heated for 30 minutes and was allowed to cool immediately under running tap water. Blank was prepared using distilled water. A pink colour solution was produced and the colour absorbance was measured using a single beam spectrophotometer (Genesys 20 Thermo Scientific, USA) at $538 \mathrm{~nm}$. The spectrophotometric results were multiplied by a constant value of 7.8 and the TBA values were expressed as mg malonaldehyde per $\mathrm{kg}$ fish.

\section{Total Volatile Base Nitrogen (TVBN) and Trimethylamine (TMA) test}

The TVBN and TMA were measured by distillation method according to method reported by Orak and Kayisoglu [7]. The fish extract was prepared by homogenising $100 \mathrm{~g}$ of sample with $200 \mathrm{~mL}$ of $7.5 \%$ (v/v) aqueous trichloroacetic acid solution, after which the solution was filtered through Whatman No.1 filter paper. An amount $25 \mathrm{~mL}$ of filtrate was poured into a distillation tube followed by $5 \mathrm{~mL}$ of $10 \%(\mathrm{w} / \mathrm{v})$ aqueous sodium hydroxide solution and distilled for 3 minutes. Distillate was collected in $15 \mathrm{~mL}$ of $4 \%(\mathrm{v} / \mathrm{v})$ boric acid that contained 0.04 
$\mathrm{mL}$ indicator (methyl red and bromocresol green) until final volume was up to $50 \mathrm{~mL}$ and then titrated with $0.05 \mathrm{M}$ sulfuric acid. For TMA measurement, the same experimental procedure was carried out as in TVBN and the only difference was the addition of $20 \mathrm{~mL}$ of $35 \%(\mathrm{v} / \mathrm{v})$ formaldehyde to the distillation tube. The amount of TVBN and TMA were calculated from the volume of $0.05 \mathrm{M}$ sulfuric acid used for titration and the results were expressed in $\mathrm{mg} \mathrm{N} / 100 \mathrm{~g}$ of fish. The following formula equation 1 was used [8]:

$$
\text { TVBN or TMA }(\mathrm{mg} \mathrm{N} \text { per } 100 \mathrm{~g})=\frac{14(\mathrm{~g} / \mathrm{mol}) \times \mathrm{a} \times \mathrm{b} \times 300}{\text { Volume of filtrate }}
$$

where, a is defined as volume $(\mathrm{mL})$ of sulfuric acid, $b$ is defined as molarity of sulfuric acid

\section{Statistical analysis}

All analyses were carried out in triplicate. Statistical analysis of data was carried out using analysis of variance (ANOVA) and the analytical procedure of Scientific Package of Social Science (SPSS) 15.0. Duncan's multiplerange test was used to determine the differences among mean values between storage conditions and storage time at $\mathrm{p}<0.05$.

\section{Results and Discussion}

Figure 1 indicated the PV of both chilled and frozen mackerel significantly increased $(\mathrm{p}<0.05)$ with storage time and generally the rate was significantly higher in chilled than frozen mackerel. The chilled and frozen mackerel started to become rancid as the PV were beyond the acceptable limit at day $15(2.10 \mathrm{mEq} / \mathrm{kg})$ and day $18(2.28$ $\mathrm{mEq} / \mathrm{kg}$ ), respectively. According to Orak and Kayisoglu [7], the acceptable limit for peroxide value was 2.0 $\mathrm{mEq} / \mathrm{kg}$. Fish oil is one of the highly unsaturated oils where peroxides initially formed are unstable and can react quickly to form secondary oxidation products [9]. Therefore, PV measurement alone is not a parameter reliable in measuring the oxidation of fish oil and for this reason the PV should be used in conjunction with other methods such as TBA test.

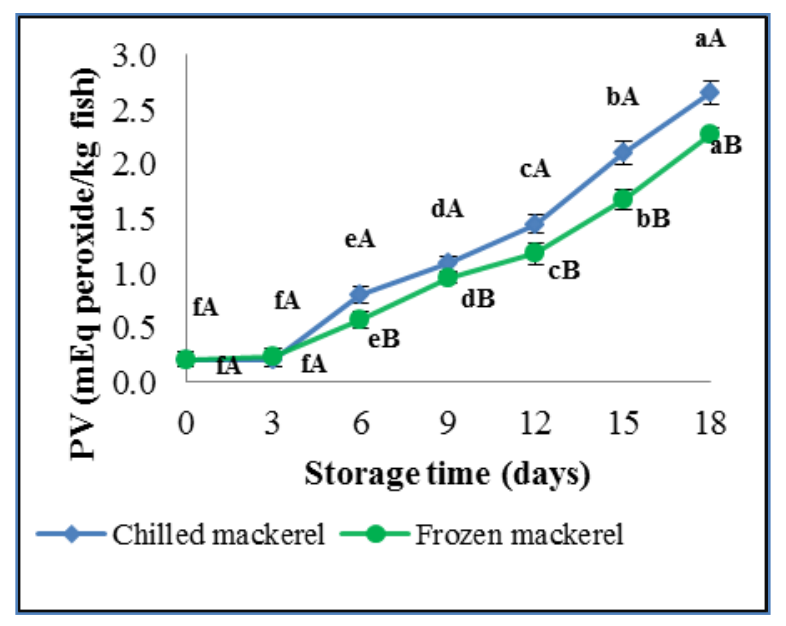

Figure 1. Changes in Peroxide Value of short-bodied mackerel in chilled and frozen storage for 18 days. Values are expressed as mean (A, B) and (a, b, c) marked with different letters were significantly different at $\mathrm{p}<$ 0.05 . Lower case letters indicate the effect of storage time on short bodied-mackerel while upper case letters indicate the effect of storage conditions.

The TBA value is widely used as an indicator for the degree of lipid oxidation according to Tokur et al. [6]. The TBA number is a measurement of malonaldehyde (MDA), which is a by-product of lipid oxidation. The MDA 
content was significantly increased $(\mathrm{p}<0.05)$ with storage time for both chilled and frozen mackerel, and the rate of increase was higher in chilled than frozen mackerel (Figure 2). Similar phenomenon was reported by Boran et al. [2] where the PV and TBA in fish oils extracted from horse mackerel, shad, garfish and golden mullet were increased with increasing storage time for both storage temperatures. The increasing of the TBA values during frozen storage also has been demonstrated by Rosari et al. [10] where with longer storage days, the TBA values were increased slowly but still not reaching the rejection limit at day 18 for milkfish.

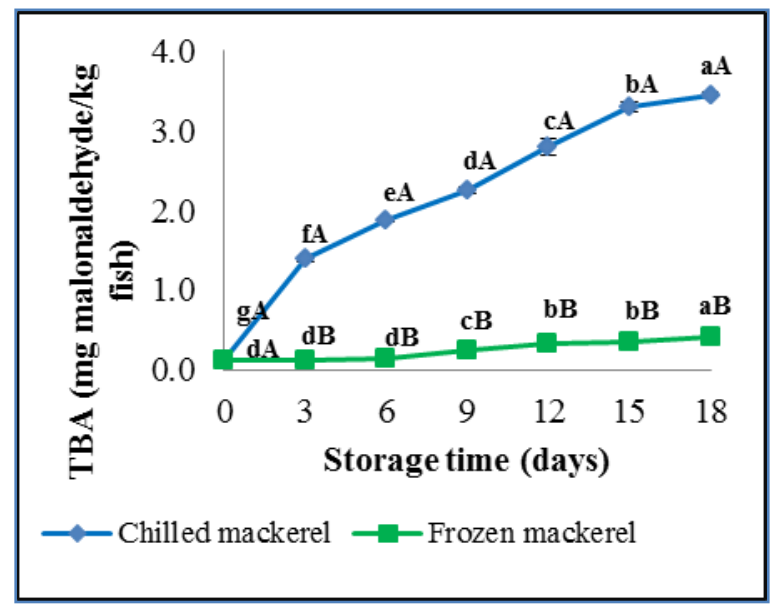

Figure 2. Changes in Thiobarbituric acid (TBA) of short-bodied mackerel in chilled and frozen storage for 18 days. Values are expressed as mean (A, B) and (a, b, c) marked with different letters were significantly different at $p<0.05$. Lower case letters indicate the effect of storage time on short bodied-mackerel while upper case letters indicate the effect of storage conditions.

The TVBN is a term that includes measurement of trimethylamine, dimethylamine, ammonia and other volatile compound associated with fish spoilage, which increases as spoilage progresses. Figure 3 showed the TVBN of chilled mackerel increased significantly $(\mathrm{p}<0.05)$ during storage time, but the values for frozen mackerel declined slowly. A similar pattern of increasing in TVBN values for the control has been reported by Sallam [3] during shelf life evaluation of sliced salmon at chilled condition. According to Raouf et al. [11], this trend was due to the denaturation of muscle protein by surviving microorganisms. On the other hand, the decrement of TVBN values in frozen mackerel may due to the fact that low temperature caused the bacteria become inactive and hence slower the rate of deterioration. The acceptable limit for TVBN that had been stipulated by literatures [7, 12] was 35 $\mathrm{mgN} / 100 \mathrm{~g}$ sample. Hence, in this study the chilled mackerel had reached the maximum limit at day 9 with TBVN value of $69.91 \mathrm{mgN} / 100 \mathrm{~g}$.

Changes in TMA levels were shown in Figure 4 where similar pattern had been demonstrated in TVBN results for both chilled and frozen mackerel. Trimethylamine (TMA) is usually used to determine the quality of fish because it is rapidly accumulated in the fish muscle under chilled condition. The TMA is always related to the pungent odour occurred in fish muscle and in this study, only chilled mackerel gave pungent odour while frozen mackerel still maintain the fishy odour until the day 18 . For chilled mackerel, the TMA values were significantly increased $(\mathrm{p}<$ 0.05 ) during storage period while for frozen mackerel the values decreased slowly. The acceptable limit for TMA was $8 \mathrm{mgN} / 100 \mathrm{~g}$ as indicated by Orak and Kayisoglu [7], and remarkably in this study, the chilled mackerel reached maximum acceptable limit at day $6(8.31 \mathrm{mgN} / 100 \mathrm{~g})$. For frozen short-bodied mackerel, similar trend was reported by Orak and Kayisoglu [7] for filleted gray mullet where the TMA values were not significantly affected by storage time. This trend could be due to inhibitory effects of freezing on the bacterial activities and hence avoid accumulation of TMA in the muscle. 


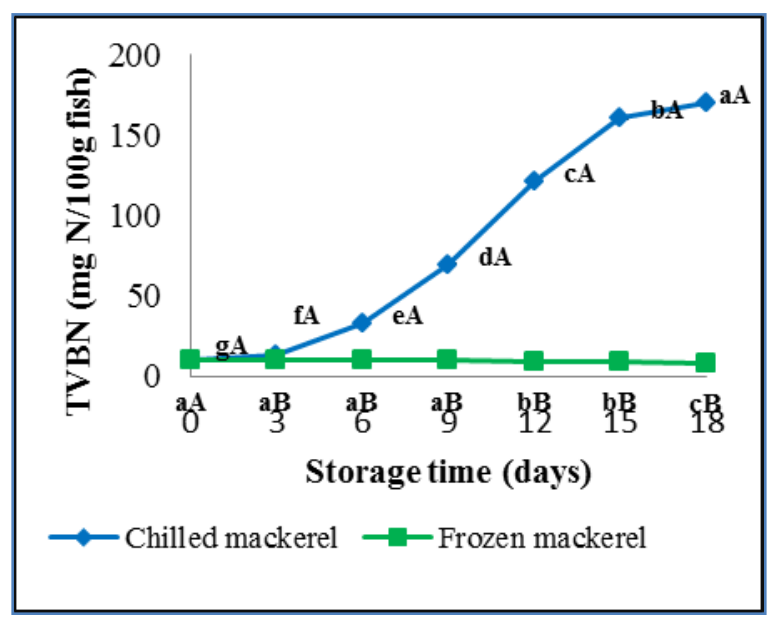

Figure 3. Changes in Total Volatile Base Nitrogen (TVBN) of short-bodied mackerel in chilled and frozen storage for 18 days. Values are expressed as mean (A, B) and (a, b, c) marked with different letters were significantly different at $\mathrm{p}<0.05$. Lower case letters indicate the effect of storage time on short bodiedmackerel while upper case letters indicate the effect of storage conditions.

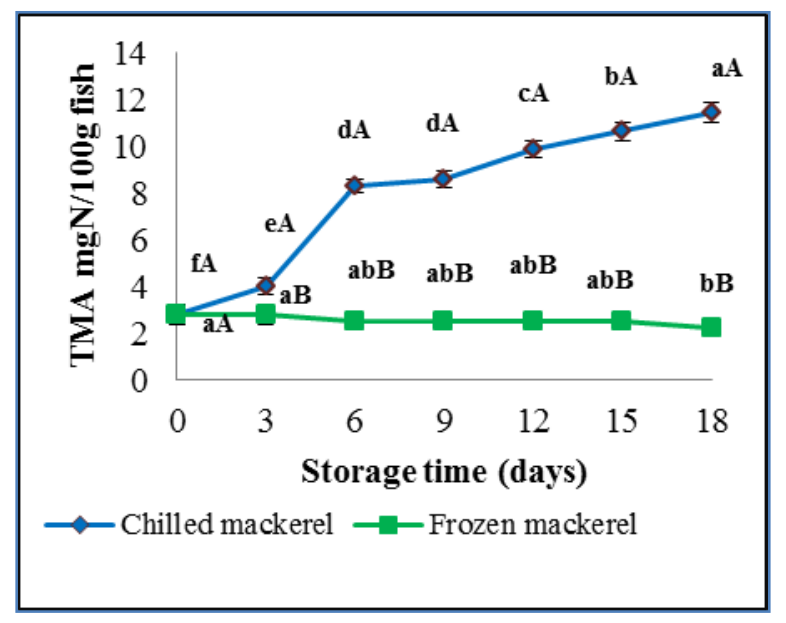

Figure 4. Changes in Trimethylamine (TMA) of short-bodied mackerel in chilled and frozen storage for 18 days. Values are expressed as mean $(\mathrm{A}, \mathrm{B})$ and $(\mathrm{a}, \mathrm{b}, \mathrm{c})$ marked with different letters were significantly different at $\mathrm{p}<0.05$. Lower case letters indicate the effect of storage time on short bodied-mackerel while upper case letters indicate the effect of storage conditions.

\section{Conclusion}

There were significant differences in the rate of chemical changes for both chilled and frozen mackerel during 18 days of storage. Frozen mackerel had a slower rate of deterioration than chilled mackerel in terms of oxidative rancidity and microbial activity. Therefore, frozen temperature $\left(-18{ }^{\circ} \mathrm{C}\right)$ can be used in food industry to prolong the shelf life of fish and hence could produce high quality finished products.

\section{Acknowledgement}

The researchers would like to thanks the European Commission (EU Grant no. 289282) for the financial support and Universiti Teknologi MARA for the technical facilities. 


\section{References}

1. Sallam, K. I., (2007). Antimicrobial and antioxidant effect of sodium acetate, sodium lactate, and sodium citrate in refrigerated sliced salmon. Journal of Food Control, 18 (5): 566 - 576.

2. Boran, A. G. K., Karac, A. M. B. H. and Boran, B. M. (2006). Changes in the quality of fish oils due to storage temperature and time. Food Chemistry, 98: 693 - 698.

3. Sallam, K. I. (2007). Chemical, sensory and shelf life evaluation of sliced salmon treated with salts of organic acids. Food Chemistry, 101 (2): $592-600$.

4. Association of Official Analytical Chemists, AOAC (1990), Official methods of analysis of the Association of Official Analytical Chemists. 15 ed. Washington D.C: Association of Official Analytical Chemist.

5. Razak, Z. K. A., Basri, M., Dzulkefly, K., Razak, C. N. A. and Salleh, A. B. (2001). Extraction and characterization of fish oil from Monopterus albus. Malaysian Journal of Analytical Sciences, 7 (1): 217 - 220.

6. Tokur, B., Korkmaz, K. and Ayas. D. (2006). Comparison of two thiobarbituric acid (TBA) method for monitoring lipid oxidation in fish. EU Journal of Fish and Aquatic Sciences, 23 (3-4): 331 - 334.

7. Orak, H. and Kayisoglu, S. (2008). Quality changes in whole, gutted and filleted three fish species (Gadus euxinus, Mugil cephalus, Engraulis encrasicholus) at frozen storage period $\left(-26{ }^{\circ} \mathrm{C}\right)$. Acta Scientiarum Polonorum Technologia Alimentaria, 7 (3): 15 - 25.

8. Zeway, A. L. A. (2013). Microbiological and chemical changes of nile tilapia (Oreochromis niloticus L.) fillet during ice storage: Effect of age and sex. Advance Journal of Food Science and Technology, 5(10): 1260 1265.

9. Saeed, S. and Howell, K. N. (2002). Effect of lipid oxidation and frozen storage on muscle proteins of Atlantic mackerel (Scomber scombrus). Journal of the Science of Food and Agriculture, 82: 579 - 586.

10. Rosari, M. I., Ma'arut, W. F. and Agustini, T. W. (2014). Pengaruh ekstrak kasar buah mahkota dewa (Phaleria macrocarpal) sebagai antioksidan pada fillet ikan bandeng (Chanos chanos forsk) segar. Jurnal Pengolahan dan Bioteknologi Hasil Perikanan, 3 (2): 34 - 43.

11. Raouf, M., Saloua, S. and Insaf, B. (2009). Quality changes of the mediterranean horse mackerel (Trachurus mediterraneus) during chilled storage: The effect of low-dose gamma irradiation. Radiation Physics and Chemistry, 78 (4):288 - 292.

12. Ojagh, S. M., Rezaei, M., Razavi, S. H. and Hosseini, S. M. H., (2010). Effect of chitosan coatings enriched with cinnamon oil on the quality of refrigerated rainbow trout. Food Chemistry, 120:193 -198. 